\title{
Stosunki wojska ze społeczeństwem Wielkiego Księstwa Litewskiego w połowie XVII wieku w świetle poezji okolicznościowej
}

Mirosław Nagielski 
クAPIS Seria VII 2001

\section{Mirosław Nagielski}

\section{Stosunki wojska ze społeczeństwem Wielkiego Księstwa Litewskiego w połowie XVII wieku w świetle poezji okolicznościowej}

$\mathrm{O}$ stosunkach między wojskiem a społeczeństwem litewskim w epoce nowożytnej pisało niewielu historyków. Dla XVI wieku mamy dokładne studium wojny inflanckiej $z$ lat 1576-1582, które jednak marginalnie odnosi się do kwestii funkcjonowania wojska na leżach już po zakończeniu kampanii przeciwko Moskwie ${ }^{1}$. Z innych prac ściśle na temat wojska litewskiego i źródeł jego finansowania warto wymienić prace Henryka Wisnera ${ }^{2}$ i Andrzeja Rachuby ${ }^{3}$. Natomiast relacji pomiędzy towarzystwem chorąiewnym a szlacheckim społeczeństwem Rzeczypospolitej bezpośrednio dotyczą drobne przyczynki tegoż $\mathrm{H}$. Wisnera - drobne, gdyż temat ten wymaga dalszych badań, a głównie żmudnych kwerend w aktach grodzkich i ziemskich poszczególnych ziem i województw litewskich ${ }^{4}$.

Jak już zauważył Henryk Wisner, okres „potopu” sprzyjał zamknięciu szeregów „starego” zawodowego wojska litewskiego. Uczyniona przez Jana Kazimierza 10 września 1655 roku darowizna dóbr po Januszu Radziwille określała ściśle beneficjantów, z wyłączeniem tych żołnie-

\footnotetext{
1 Zob. H. Kotarski, Wojsko polsko-litewskie podczas uojny inflanckiej 1576-1582, cz. 1-5, „Studia i Matcriały do Historii Wojskowości" (dalcj: SMHW), t. 16 (1970), cz. 2, s. 63-123; t. 17 (1971), cz. 1, s. 51-124; cz. 2, s. 81-151; t. 18 (1972), cz. 1, s. 3-92; cz. 2, s. 43-104.

2 Zob. H. Wisncr, Wojsko litewskie 1. polow XVII wieku, cz. 1-3, SMHW, t. 19 (1973), cz. 1, s. 61-138; t. 20 (1976), s. 5-26; t. 21 (1978), s. 45-148.

${ }^{3}$ Zob. A. Rachuba, Sity zbrojne Wielkiego Księstwa Litewskiego w XVII wieku, „Przcgląd Wschodni”, t. 3 (1994), cz. 3, s. 379-410.

${ }^{4}$ Mamy tu na myśli przede wszystkim prace Henryka Wisncra: Wojsko w społeczeństurie litewskim pierwszej połouy XVII wieku, „Przcgląd Historyczny”, t. 66 (1975), z. 1, s. 41-60; Przedsejmouy sejmik nowogrodzki w latach 1607-1648, „Przegląd Historyczny”, t. 69 (1978), z. 4, s. 677-693; Wojsko Wielkiego Księstua Litewskiego. Czasy Zygmunta III i Wladyslawa IV, „Zeszyty Naukowe WSP w Opolu”, Historia 26, 1988, s. 217-233.
} 
rzy, którzy dopiero w latach następnych weszli do służby. Stąd ci pierwsi zabiegali o to, aby liczba żołnierzy dopuszczonych do tej nagrody nie wzrastała. Faktyczną ugodę przeprowadzono dopiero w roku 1662. Natomiast stosunek szlachty litewskiej do własnego wojska był zróżnicowany. Jej liczba, według badań Józefa Morzego, nie była aż tak wysoka jak w Koronie, ponieważ w pierwszej połowie XVII wieku, przed okresem wielkich wojen (1648-1667), rycerstwa zdolnego do noszenia broni w ramach pospolitego ruszenia rachowano nie więcej niż 23 tys. ${ }^{5}$ Oczywiście zawodowa armia litewska była bardzo nieliczna i przed wojną z Moskwą i Szwecją wynosiła zaledwie kilka tysięcy ludzi. Przykładowo: w działaniach hetmana polnego litewskiego Janusza Radziwiłła w kampanii łojowskiej 1649 roku wzięło udział około 7 tys. ludzi, nie licząc powiatowych chorągwi ${ }^{6}$. Pamiętajmy jednak, że obok Litwinów w skład tych sił wchodziły jednostki zaciągu cudzoziemskiego (piechota tzw. niemiecka, rajtaria i dragonia) oraz posiłki z Korony (jak w kampanii zimowo-wiosennej obu Radziwiłłów, Bogusława i Janusza, w latach 1654-1655).

W 1659 roku armia litewska, podzielona organizacyjnie na dwa skrzydła, wynosiła ok. 20 tys. żołnierzy, z czego zaledwie połowa przypadała na choragwie zaciągu towarzyskiego, w których teoretycznie dominowała szlachta. Utrwaliło się stąd w społeczeństwie litewskim przekonanie o szlacheckim charakterze wojska Wielkiego Księstwa Litewskiego, choć nawet w chorągwiach husarskich, i to tak elitarnych jak królewskie i hetmańskie, spotkać możemy plebejuszy nieszlacheckiego pochodzenia nie tylko wśród pocztowych, ale i towarzystwa. Wynika to z zachowanych chorąiewnych regestrów rot Wincentego Korwina Gosiewskiego, Michała Kazimierza Radziwiłła, Aleksandra Hilarego Połubińskiego (a następnie królewskiej pod jego komendą) i wielu innych. Regestry te świadczą jednoznacznie, że postępowano wbrew zaleceniom szlachty, aby werbunek do tego typu rot obejmował jedynie ja. Na przykład spośród 144 nazwisk towarzystwa, występujących w regestrach z lat 1648-1653 chorągwi husarskiej wspomnianego Połubińskiego, podkomorzego słonimskiego, współcześnie żyjący Wojciech Wijuk Kojałowicz znał jedynie 13 (9 proc.), a spośród 125 nazwisk w obu swoich herbarzach umieścił zaledwie 65 (52 proc.) ${ }^{7}$. Rezultaty badań nie uległy większym zmianom przy uwzględnieniu innych herbarzy (Adama Bonieckiego, Kaspra Niesieckiego i Seweryna Uruskiego) ${ }^{8}$. Podobnie wyglądała sytuacja w innych choragwiach husarskich armii litewskiej. W rocie hetmana polnego litewskiego Wincentego Korwina Gosiewskiego liczba znanych heraldykom nazwisk jej towarzystwa spadała wraz z wielkością pocztu przez nie wystawianego. Tak oto na liczbę 15 towarzyszy wystawiających 4-6-konny poczet Kojałowicz znał cztery nazwiska, a Niesiecki sześć, podczas gdy z 11 towarzyszy służących z dwukonnym pocztem obaj heraldycy nie notują żadnego 9 . Zresztą wielu plebejów za zasługi wojenne otrzymywało później nobilitacje za wstawiennictwem hetmanów.

Duży odsetek żołnierzy plebejskiego pochodzenia (30-40 proc.) nawet w zaciagu narodowym (w którego skład wchodziły roty husarskie, kozackie, piechota polsko-węgierska) decydował

5 Zob. J. Morzy, Kryzys demograficzny na Litwie i Biatorusi w II potowie XVII wieku, Poznań 1966.

6 Zob. H. Wisner, Działalnośc wojskowa Janusza Radziwilla 1648-1655, „Rocznik Białostocki”, t. 13, Warszawa 1976, s. 53-109 (zwł. s. 73-75).

7 Zob. W. Kojałowicz, Herbarz rcerstiva W. Ks. Litewskiego zwany „Compendium”, Kraków 1897; idem, Herbarz szlachty W. Ks. Litewskiego zwany „Nomenclator”, Kraków 1905.

${ }^{8}$ Zob. M. Nagiclski, Chorqgwie husarskie Aleksandra Hilarego Polubińskiego i króla Jana Kazimierza w latach 1648-1666, „Acta Baltico-Slavica”, t. 15, Wrocław 1983, s. 90-91.

9 Zob. H. Wisner, Wojsko w spoleczeństwie litewskim..., op. cit., s. 49. 
o poziomie dyscypliny wśród żołnierzy, zarówno w trakcie prowadzonych działań wojennych, jak i przede wszystkim na leżach, gdy szlachta absentowała się spod chorągwi, udając się do domowych pieleszy. Niesubordynację i słabe morale wojska pogarszały przegrane kampanie sił litewskich $z$ oddziałami rosyjskimi i szwedzkimi w latach 1654-1658, tym bardziej, że oddziały litewskie, zachowujące się na leżach jak w obcym kraju, nie mogły liczyć na oparcie we własnym społeczeństwie. Majątki szlacheckie bowiem były plądrowane w równym stopniu przez obcego, co i własnego, nieopłacanego żołnierza, który musiał wyżywić się sam, kosztem terenu, na którym przebywał. Stąd, jak to widać z licznych protestacji w księgach grodzkich i ziemskich, dochodziło do częstych zatargów pomiędzy choragwiami a szlachta gospodarująca w swoich folwarkach. Punkt widzenia jednych i drugich był zupełnie odmienny. Świetnie ilustruje to wypowiedź znanego pułkownika lisowczyków Jarosza Kleczkowskiego, który w początkach 1620 roku wprost stwierdzał:

Nie nowinać to, że ludzie rycerscy, lubo z przyrodzenia pokoju nie cierpiący, chleba sobie dostawają szablą, ale to dziwna, gdy bracia, jednejże matki synowie, wzajem się znosić usiłują — dla fraszek i dość znośnych stacji, bez których ani być, ani żyć nie może żołnierz ${ }^{10}$.

Oczywiście nie tylko na Litwie wojsko dawało się we znaki społeczeństwu; każdy bowiem przemarsz oddziału czy długotrwały pobyt na leżach wiązał się z ruiną dóbr nie tylko królewskich czy duchownych, ale i szlacheckich w tej okolicy. Znaczne zmniejszenie rangi zawodu żołnierskiego w społeczeństwie, na co wskazuje wielu historyków, wiązać należy z niemożnością wykonywania przezeń podstawowego zadania — skutecznej obrony granic Wielkiego Księstwa Litewskiego. To właśnie krytykowali Nowogrodzianie w omawianym poniżej rękopiśmiennym paszkwilu na jedną z rot husarskich, stacjonującą w ich dobrach.

W połowie roku 1659 chorąwie sapieżyńskie czekały na postanowienia sejmu warszawskiego, lupiąc jednocześnie województwo nowogrodzkie i wileńskie. Latem bowiem tego roku, w związku z postępami sił moskiewskich na zachód od rzeki Berezyny (mimo starań broniących jej linii oddziałów Samuela Oskierki i Denisa Muraszki), hetman wielki litewski ponaglany ze strony dworu królewskiego zdecydował się na kontrakcję. Z dywizji prawego skrzydła wojska litewskiego wydzielił oddział pod komendą kasztelana połockiego Jana Sosnowskiego, który miał ruszyć pod Mińsk i wraz z chorągwiami powiatowymi szlacheckimi przeciwstawić się nowej ofensywie wojsk moskiewskich. Droga tych rot w kierunku Mińska i Bobrujska zaznaczyła się pożogami i rabunkami nie tylko dworów szlacheckich, ale i małych miasteczek. Już pojawienie się w Nowogródczyźnie pierwszych choragwi litewskich wprawiło w panikę obywateli tegoż województwa. Obawiali się bowiem bardziej własnego żołnierza niż moskiewskiego, gdyż Litwini nie otrzymywali żołdu począwszy od 1654 roku i tym tłumaczyli kontrybucje nakładane na szlachtę nowogródzką i mińską ${ }^{11}$. Tymczasem do wojska dotarły nowiny z sejmu walnego (22 III-30 V 1659), który pominął

\footnotetext{
${ }^{10}$ Ibidem, s. 53.

1 Zob. list K. Kłokockicgo i W. Huryna do Bogusława Radziwiłła ze Słucka 12 VIII 1659 — Archiwum Główne Akt Dawnych w Warszawic, Archiwum Radziwiłlowskic (dalcj: AGAD, AR), dz. V, nr 6865/1, s. 105-106.
} 
wiele postulatów wojska litewskiego. Jeszcze ostatniego dnia sejmu Jan Kazimierz, zdając sobie sprawę z nastrojów wśród Litwinów, wydał oficjalny respons posłom od obu skrzydeł armii litewskiej. Godził się w nim z kilkoma dezyderatami wojska, między innymi z następującymi:

- wojsku zostanie wypłacony zaległy żołd (dlatego zdecydowano się podnieść akcyzę i pogłówne żydowskie);

— wojsko otrzyma zaliczkowo pewne kwoty z dóbr po Januszu Radziwille w zamian za opuszczenie dóbr Bogusława Radziwiłła, koniuszego litewskiego (ale musi się z nim samo porozumieć);

- obiecane sumy od Jerzego II Rakoczego będą dotyczyć także wojska litewskiego, czyli tych żołnierzy z grupy Aleksandra Połubińskiego, którzy wzięli udział w walkach z siłami Siedmiogrodzian;

- skarb Rzeczypospolitej wyłoży konieczne fundusze na wykup z niewoli moskiewskiej hetmana polnego litewskiego Wincentego Korwina Gosiewskiego i jego oficerów, którzy wpadli $\mathrm{w}$ ręce rosyjskie w trakcie batalii pod Werkami.

Jednym słowem, Jan Kazimierz wydał wojsku litewskiemu asekurację, że ich zasługi będą całkowicie zaspokojone na przyszłym sejmie, a rotmistrzom nakazano, aby utrzymali towarzystwo w dalszej służbie do 5 sierpnia 1659 roku bez pieniędzy ${ }^{12}$.

Odpowiedź króla nie mogła zadowolić towarzystwo chorąiewne, które miast deklaracji czekało na konkretne uchwały podatkowe. Stąd zapewne kilka dni później Jan Kazimierz w obawie przed konfederacją wysłał do wojska swych posłów: Krzysztofa Wołodkiewicza, wojewodę nowogrodzkiego i Piotra Galińskiego, starostę orszańskiego, aby utrzymali oddziały litewskie w dalszej służbie ${ }^{13}$.

Nadal jednak dywizja prawego skrzydła (sapieżyńska) nie łączyła się z dywizją żmudzką, pozostającą w Kurlandii pod komendą Samuela Komorowskiego, oboźnego litewskiego. Chorągwie sapieżyńskie, rozłożone w województwach mińskim i nowogrodzkim, czekały na komisarzy i zaległe ćwierci, wybierając sobie należności w naturze i pieniądzu. Aby pobudzić żołnierzy do działania i opuszczenia zajętych powiatów, 8 lipca Jan Kazimierz wydał nowy uniwersał, w którym informował o naznaczeniu na 5 sierpnia w Mostach komisji mającej obmyślić zapłatę dla armii litewskiej. W kolejnym ordynansie z 10 lipca uspokajał żołnierzy, że w sprawie dóbr radziwiłłowskich także zostaną ukontentowani ${ }^{14}$. Tego samego dnia Jan Kazimierz przekazał komendę nad siłami przeznaczonymi przez Pawła Sapiehę na wyprawę do Kurlandii wspomnianemu wcześniej Aleksandrowi Hilaremu Połubińskiemu, dowódcy pułku królewskiego w prawym skrzydle litewskim. W skład delegowanych chorągwi miała wchodzić także rota husarska króla, której pisarz polny litewski był porucznikiem ${ }^{15}$.

\footnotetext{
12 Zob. reskrypt Jana Kazimicrza dany posłom regimentu Pawła Sapichy, Warszawa 30 V 1659 - AGAD, AR, dz. II, teka $10, \mathrm{nr} 1382$.

${ }_{13}$ Zob. Instrukcja Jana Kazimierza dana komisarzom, Warszawa 8 VI 1659 - AGAD, AR, dz. II, tcka 10, nr 1383.

${ }_{14}$ Zob. Uniwersał Jana Kazimierza do wojska litewskiego z Nieporętu 8 VII 1659 - rps Bibliotcki Czartoryskich w Krakowic (dalej: BCzart.), sygn. 152, nr 50; Reskrypt JKMci na punkta regimentu Pawła Sapichy z Warszawy 10 VII 1659 - AGAD, AR, dz. II, tcka 10, nr 1386.

${ }_{15}$ Zob. AGAD, AR, dz. III, kop. 7, nr 204 i 205; por. Komput choragwi ordynowanych z obozu spod Gicgużyna do Kurlandii - AGAD, AR, dz. V, nr 11208, cz. 1, s. 156-157.
} 
Prezentowane obecnie drobne utwory poezji okolicznościowej (ze zbiorów Biblioteki Jagiellońskiej w Krakowie ${ }^{16}$ ) powstały zapewne w czerwcu lub początkach lipca roku 1659, gdy choragiew husarska JKMci przebywała na leżach w województwie nowogrodzkim i zbierała się do wymarszu ku punktowi zbornemu w Giegużynie. Wiemy, że roty te miały się stawić na generalny popis 30 lipca, lecz wiele $z$ nich nie dotarło na wyznaczone miejsce, a inne odmówiły w ogóle służby, przystępując do tworzenia koła konfederackiego. Długie rozmowy przyniosły wreszcie oczekiwany efekt i Aleksander Połubiński w połowie lipca wyruszył w kierunku Kurlandii, stając 31 sierpnia pod Goldyngą ${ }^{17}$. Widzimy więc, że pobyt pułku królewskiego, w skład którego wchodziła rota husarska monarchy w Nowogródzkiem mógł przypadać na maj-czerwiec 1659 roku przed rozpoczęciem ekspedycji kurlandzkiej. Wysłanie tego korpusu na tyle jednak osłabiło siły litewskie, że nie były w stanie dać skutecznej odsieczy od dawna obleganemu przez siły moskiewskie Staremu Bychowowi. Choragwie pod komendą Jana Sosnowskiego i Samuela Oskierki zamiast iść pod twierdzę bronioną przez Iwana Neczaja zbuntowały się, wypowiadając posłuszeństwo dowódcom, i podążyły na Słucczyznę dla restauracji swoich pocztów ${ }^{18}$. Sytuacja zatem powtórzyła się jak w przypadku powracających z Nowogródzkiego sił litewskich, które pod Trokami także zbuntowały się wobec swego dowódcy, Aleksandra Hilarego Połubińskiego.

Autorami paszkwilu skierowanego przeciwko szlachcie z Nowogródka, niestety nieznanymi nam $z$ imienia, byli dwaj towarzysze chorągwi husarskiej JKMci poruczeństwa pisarza polnego litewskiego Aleksandra Połubińskiego: Szymanowski i Berk. Pierwszy pochodził z mazowieckiego rodu herbu Ślepowron, osiadłego głównie w ziemi sochaczewskiej i warszawskiej. Natomiast Berk (Berek) zapewne wywodził się ze znanej rodziny inflanckiej. Obaj prawdopodobnie zaciągnęli się w szeregi husarii królewskiej podczas rekrutacji po batalii warszawskiej (28-30 lipca 1656 roku), gdzie rota owa poniosła olbrzymie straty w drugim dniu bitwy. Otojak imć pan Szymanowski ocenia panów Nowogrodzian, którzy okazali się niewdzięcznymi synami Rzeczypospolitej, żałując strawy zasłużonemu rycerstwu litewskiemu:

\section{Paszkwil na hojność województwa nowogrodzkiego od wojska Wielkiego Księstwa Litewskiego na leży w tymże województwie będącego, którym $z$ dobrego afektu szlachta chleb $z$ dóbr swych pozwoliła brać roku 1659 przez pana Szymanowskiego towarzysza JKMci chorągwi usarskiej}

Darmo wąsem potrząsasz, usarzu wspaniały, I cieszysz się nadzieją, że za czas już mały Biedzie koniec uczynisz, i przetrwawszy tyle,

\footnotetext{
16 Sygn. BJ Akc. 217/61, k. 165-167v.

17 Zob. J. Jasnowski, Aleksander Hilary Polubiniski. Działalnoś wojskowa w latach 1650-1665, „Przegląd Historyczno-Wojskowy", t. 10 (1938), s. 170-172.

${ }_{18}$ Zob. list K. Kłokockicgo i W. Huryna do Bogusława Radziwiłła ze Słucka 21 XI 1659-AGAD, AR, dz. V, nr 6865, cz. 1, s. 151-153.
} 
Znaczną uznasz podporę w weredzinej ${ }^{19}$ sile!

Że w oczach Nowogródek, tym cię nowe duchy

Omylające zawsze zbijają otuchy,

Rozumieszże, kopija ${ }^{20}$, że miasto ochoty,

Że tu wczasy wynajdziesz i lube pieszczoty.

Ale i dzielne konie, wy konie wspaniałe,

Na cóż darmo lamiecie karki okazałe,

I wszelako nad zwyczaj ukazując cerę,

W nowąście się przybrali teraz manijerę?

Darmo w was bliskie miasto chęć wzbudza zawodu,

W którym prędko musicie pozdychać od głodu.

Hojni tu chlebodawcy ci Nowogrodzianie,

Na koń jeden po całym nie dają baranie;

Odmienisz głos, usarzu, pod tutejszym niebem,

Nieprzywykłym żołądek przełożywszy chlebem;

A kiedyby ${ }^{21}$ przynajmniej w nim się oni stali,

Żeby więcej niż beczkę tego chleba dali!

Kiedy w gardle zawięźnie, napić by się trzeba,

Inaczej tak smacznego nie przebędziesz chleba -

Chyba kwasu, usarzu niebożę, zażyjesz;

Piwa $z$ beczki, jęczmienia za pół dnia wypijesz.

Więc $z$ owej jałowice czy nogi, czy rogi,

Czy się głowa dostanie do kuchnie ubogiéj,

Znaczne to tedy skąpstwo jednak nagrodzili,

Kiedy po garcu grochu $z$ włóki naznaczyli.

W poście było, nie teraz; $z$ takowej ustawy

Za Bachusowe święta żądają potrawy.

Szczęśliwy flis, w Mazowszu co szkuty pilnuje,

Chocia pojazdą 22 robi, chocia nie wojuje;

Trudów żadnych nie cierpi i krwie nie przelewa,

Codziennie grochu garniec na swój obiad miewa,

A w nim takowy karwasz ${ }^{23}$ wybornej słoniny,

Co by na rok wystarczył do waszej botwiny!

Wyraźnie zatem towarzystwo husarskie wyrażało dezaprobatę wobec chytrych Nowogrodzian, którzy żałują strawy braciom walczącym z Moskwą. Znacznie jednak ostrzejszy atak na okoliczną szlachtę przypuścił drugi towarzysz tej chorągwi. Wprost zarzucił „braci”, że gdy

19 Wereda — brzydota, szkarada; tu możc: zmicnna, niestała (z ukr. weredun - grymaśnik)?

${ }^{20}$ Kopija — tu: kopijnik, husarz (adresat przemowy w wicrszu); w rpsie: Rozumiesz, że kopia.

${ }^{21}$ Kiedyby - gdybyż; oby! (życzenic).

22 Pojazda - wiosło.

${ }^{23}$ Karwasz (z wçg. dosł.: 'naramiennik') — tu: połeć, kawal. 
Moskwa zajęła Nowogródczyznę, w obawie o życie i mienie nie skąpiła jej strawy i wszelakiego dobra, dogadzając żołnierzom nieprzyjacielskim, podczas gdy obecnie żałują chleba własnemu rycerstwu. Pamiętajmy bowiem, że siły moskiewskie zajęły województwo nowogrodzkie już w 1655 roku i niemal do roku 1659 jego duża część znajdowała się pod okupacją sił Iwana Chowańskiego i innych dowódców carskich. Przedstawmy więc ciąg dalszy oskarżenia Nowogrodzian, tym razem w wydaniu imć pana Berka:

\section{Item w tejże materii przez pana Berka, tejże chorągwie towarzysza}

Pozorny w czasiech ${ }^{24}$ bywał ludziom $z$ dawna

Cny Nowogródek; że zedrwiał, to jawna ${ }^{25}$,

Prędka odmiana bowiem, z Moskalami

Zostali sami.

Naprzykrzyło się z ludźmi rycerskimi

Obywatelom, tylko mowy swymi

Moskwie dank dają ${ }^{26}$, a brata swojego

Mają za złego.

Nieciężko było w Kurpiach od żołdata

Cierpieć zniewagę, a ciężej od brata;

Nie większaż ${ }^{27}$ kłamać chłopowi sprośnemu

Niż bratu swemu,

Tak mówiąc? A my ukłonu nie chcemy,

Chleba nam dajcie, to wdzięcznie przyjmiemy,

Tylko nie berła ${ }^{28}$, co to w pół z plewami,

Jedzcie to sami.

Rzeczecie pono: "Jak to wydziwiaja!

Czemuż wżdy Moskwa ten z nami jadają?” -

Zjad[1]szy ogórek, szmat słonej kapusty

Już Moskal tłusty.

Dobrzeście pewnie karmili i smaczno

W tym województwie, barzo bowiem znaczno,

Bo jako wieprze utyli z dostatku

Aż do pośladku;

Rzadka się szabla tego połcia jęła,

Jedna spadała, druga w dubę zgięła ${ }^{29}$,

Tłusto karmieni, psom do pożywienia

I do zjedzenia.

24 Pozorny — okazały, zamożny; w czasicch — dawnicj, nicgdyś.

${ }^{25}$ Zedrwiał - tu zapewne: zmarniał, pogorszył sic̨; jawna - jasne, oczywiste.

${ }^{26}$ Dank dają - hołdują, dziçkują.

27 Nic większaż — tu: nic lcpicj byłoby...?

${ }_{28}$ Bcrło - zbożc pozostałc po omłocic w plewach (chlcb berłowy — wyrobiony ze zboża z plewami).

${ }^{29}$ W dubç zgiçła — zapewne: nałożyła jarzmo. 
To Moskwę z poczty karmili miłości ${ }^{30}$,

Nam też co dajcie, prosim, waszej włości;

Jeśli chudego chcecie dać barana

Dla cara pana,

To zachowajcie, a nam jałowicę

Przy połciach tłustych, smaczną polędwicę,

Dobre są schaby, kiszki z kiełbasami,

To zjemy z wami.

Głowizna niezła; ba, i podwędzizna ${ }^{31}$

Z kapustą dobra, każdy to $z$ was przyzna,

Sadełka trzeba dla drobnej czeladzi,

To nie zawadzi,

A za barana skopu dać dobrego,

Żeby tym głosu nie odmienił swego

Usarz wspaniały, ale mówił basem,

Jak każdym czasem;

Niezła jarzyna do miąska tłustego,

Dobre to rzeczy, dajcie nam i tego

Masła do kasze a syra do chleba

Pilno potrzeba,

Słodu na piwo dajcie pszenicznego,

A w niedostatku lubo jęczmiennego,

Tylko dostatek ${ }^{32}$, z pilnością prosiemy,

Co wypijemy

Za zdrowie wasze et chara pignora ${ }^{33}$,

Co tu w kościele byli z wami wczora,

Za zdrowie kmiotka, wiernej prace jego

Do dna samego.

Ale się mnie zda, że tego nie dacie,

Bo o nas, widzę, już mało co dbacie.

Gdyby osudar ${ }^{34}$, pewnie dalibyście,

A my to iście ${ }^{35}$

Mamyć to przecie, że nas wysławiacie

I w oczy dobre słowo nam dawacie;

Ale za oczy idziecie obłudnie,

30 Z poczty - wraz z pocztami; miłości - wasze miłości, waszmościowie (Nowogrodzianic).

${ }^{31}$ Podwçdzizna - wędzonka, boczek podwędzany do bigosu.

32 Dostatek - wiele, obficic.

${ }^{33}$ Et chara pignora - i lubych dziatck (łac.).

${ }^{34}$ Gdyby osudar - gdyby to był...; oczywiście chodzi o cara moskiewskiego (hosudara) Alcksego Michajłowicza, którego władzy Nowogrodzianic doświadczyli kilka lat w okrcsic „potopu”.

35 Iście - na pewno. 
Choć w oczy cudnie.

Że daliście ${ }^{36}$ nas do pana hetmana,

Od którego nam karta ${ }^{37}$ do nas dana,

Żebyśmy więcej już chleba nie brali,

Bodaj nie znali

Chleba waszego, to szczyrze mówiemy:

My to nie chlebem, lecz brakiem zowiemy,

Bośmy się prawie w niwecz obrócili,

Was zbogacili.

Berk wprost stwierdzal, że towarzystwo choragiewne głodowało na tak nędznych konsystencjach, jakie otrzymali od Nowogrodzian, którzy jeszcze ośmielili się skarżyć przed hetmanem Pawłem Sapiehą, wysyłając od siebie posłów. Otrzymali zapewne nie tylko ostry ordynans zakazujący wybierania „chleba” nad ustawę żołnierską oraz nakaz opuszczenia Nowogródczyzny wobec koncentracji choragwi przed kampanią kurlandzką. Ale rozsierdzone towarzystwo nie tylko nie zaprzestało wybierania stacji, lecz także zapewne mocno dało się we znaki niewdzięcznym mieszkańcom Nowogródczyzny.

Wiersz ten musiał jednak wywołać spore poruszenie zarówno wśród towarzystwa innych choragwi z tego pułku, jak i przede wszystkim między samymi obywatelami województwa nowogrodzkiego, którzy z dobrej woli przyjęli żołnierza na leża, a ten odpłacał im taką niewdzięcznością. Stąd zapewne zdecydowano się nie pozostawić tego paszkwilu bez odpowiedzi. W ten sposób powstała replika niewiadomego autorstwa, skierowana przeciwko rabującym i chodzącym po włości choragwiom, które miast walczyć z Moskwą wolą podkreślać swe przewagi w zagrodach chłopskich:

\section{Replika niewdzięcznemu usarzowi od województwa nowogrodzkiego}

Jeżeli którym choragwiom sfolguję,

Tobie się barziej, usarzu, dziwuję,

Żeś i ty przyszedł do takiej płochości,

Leżąc na włości;

Żeś, porzuciwszy rycerskie zabawy,

Gonitwy i wam przyzwoite sprawy,

Miasto kopijej piórem nas wojujesz,

Sławy ujmujesz.

Zadajesz to nam, żeśmy z Moskalami

Pobratali się; przypomnicież sami,

Coście wprzód panu za kunszt wyrządzili,

Gdy go zdradzili ${ }^{38}$,

${ }^{36}$ Daliścic - podaliście, złożyliścic skargę.

37 Karta - list z rozkazem, ordynans.

38 Zdrada chorągwi husarskicj JKMci pod A. H. Połubińskim rzcczywiścic miała miejsce. Przyjçła ona służbę u Karola X Gustawa wcześnic, bo już w listopadzic 1655 roku. Pisał o tym Benedykt Olszewski do Bogusława Radziwiłła z Warszawy 8 listopada 1655 roku: „...chorągiew husarską królewską wziął [król szwedzki - M. N.] za swoją i na moderunck jej pisarzowi Połubińskiemu dał kilkanaścic tysięcy; owo zgoła szabla polska bardzo mu się 
A gdy niestetyż wojskowe załogi

Już nas odbiegli, dopierośmy rogi,

Gdyśmy i pana w Ojczyźnie nie mieli,

Złożyć musieli.

Obłudę nam też jakąś przypisujesz,

A swojej wady do siebie nie czujesz,

Wprzód byś dziękować miał ${ }^{39}$ za chleb, nie żwawie ${ }^{40}$

Szczypać na sławie;

Więc i chlebowi dajecie naganę,

Jakoby zboże niedobrze wymiane ${ }^{41}$;

To nie głód, bo człek w chlebie, gdy się spości,

Nie widzi ości ${ }^{42}$.

Jużeście wszystko, co było, pobrali,

Chleb ten nie zjedli, lecz poprzepijali,

Teraz zaś znowu chleb chcecie brać, a my

Już go nie damy;

Czas też już i wam przywykać do postu,

Bo mam li prawdę rzec, rzekę po prostu:

Kto siła jada i siła w się leje,

Leżąc, gnuśnieje.

A zatym sprośnych paszkwilów niechajcie ${ }^{43}$,

Do kopijej tymczasem przywykajcie,

Bo się Bóg za to uraża na niebie,

Odda w potrzebie!

Na oskarżenia w stosunku do Nowogrodzian odpowiedział inny obywatel tegoż województwa, który poczuł się wielce urażony niewdzięcznością husarii królewskiej utrzymywanej latem 1659 roku przez szlachtę. Oto treść jego wystąpienia:

\section{Proceder wojska Wielkiego Księstwa Litewskiego w województwie nowogrodzkim na chlebie leżącego przez jednego szlachcica w roku 1659}

Straciła pierwszą już Ojczyzna cerę,

Postrzeg[ł]szy w wojsku nową manijerę,

podobała” - AGAD, AR, dz. V, tcka 241, nr 10816, s. 15-18. Fakt przcjścia nicktórych chorągwi litcwskich na służbę szwedzką był doskonale znany; przebywały one w służbie Karola X Gustawa na pólnocnym Mazowszu aż do połowy lutego 1656 roku, i dlatego szlachta nowogródzka wypominała ten fakt towarzystwu właśnie tcj chorągwi.

${ }^{39}$ Wprzód... - najpierw powinieneś...

40 Żwawic - drapicżnie, uszczypliwic.

${ }^{41}$ Wymianc - zmielonc.

42 Ości - plewy, łupiny.

${ }^{43}$ Niechajcie - poprzestańcic, porzućcic. 
I gdy obronie ich dufała stale,

$$
\text { Upadła cale }{ }^{44} \text {. }
$$

Upadła i już zaledwie nie kona,

Widząc, że słaba w jej wojsku obrona,

Bo gdy się za nię pilno bić potrzeba,

Oni do chleba;

Lecz i ten gdyby dyskretnie brać chcieli, Jeszcze by wszyscy dosyć chleba mieli, Ale się wszytko wojsko już w to wpasło,

$$
\text { „Wse bery!" hasło }{ }^{45} \text {. }
$$

Brał, co kto nalazt: dwie, trzy jałowice,

Nie chciał na połcia pojźrzeć połowicę,

Woły, barany, kury i z kurczęty,

$$
\text { Świnie z prosięty; }
$$

Obaczył wieprza, i tego wziął całkiem,

Niekontent sadła do kasze kawałkiem,

Gąska kiedy się nawinie na oczy,

W skok do niej skoczy.

Trafi li który na błahą gospodę,

Że nie ma co wziąć, to chłopa za brodę,

Samą ${ }^{46}$ po boku, a jeżeli hoża,

Wnet z nią do łoża.

Zwąchali jamę u chłopa ze zbożem,

To mu łeb kręci dokoła powrozem,

Aż mu ją powie, a skoro wykopie:

$$
\text { „Nie twoje, chłopie!" }
$$

Obaczy, jadąc że chłop sobie orze,

Jużeż niechybnie każą mu być w worze,

Wór zawiązawszy, co prędzej z wołami

$$
\text { Uchodzą sami. }
$$

To się chłop miece w worze, a tymczasem

Rżną woły w lesie lub w rowie pod lasem,

Pobiorą mięso, skórę, flaki, nogi,

$$
\text { A chłopu rogi. }
$$

Już im królewskich, już nie stało włości,

Już i szerokie pańskie majętności

Zgubili, teraz nas, szlachtę ubogą,

${ }^{44}$ Jest to przytyk do klçsk wojska litewskicgo w latach 1654-1655, w wyniku których siły moskiewskic zajęły większość województw Wielkicgo Ksiçstwa Litewskicgo wraz z Wilnem; zob. G. Saganowicz, Niewjadomaja wajna 1654-1667, Minsk 1995, s. 34-55.

${ }^{45}$ Wse bery! — „wszystko brać!" to ich hasło.

${ }^{46}$ Samą - żonę gospodarza. 
Gnębią jak mogą.

Prosili w rzeczy, żebyśmy chleb dali,

A kiedyśmy go dać deklarowali,

Wnet się nam nasza łaska $z$ dobrą wolą

Płaci niewolą.

Sami ustawy sobie popisali,

Sami i miary różne wymyślali,

I nie tą miarą, jakoś chciał, niebożę,

Musisz dać zboże.

Nie daszli, jako on każe, więc za to

Grabieżem sobie nagradza bogato,

Woły szlacheckie, leżąc na kwaterze,

Wszystkie pobierze.

A któż te wszystkie wypowiedzieć może

Ich sprawy? Tylko Ty sam, mocny Boże,

Wszytko to widzisz, gotując na ziemi

Pomstę nad niemi!

Sądźcie się z wami; czemu przegrawacie,

Czemu w potrzebie nic serca nie macie;

Tak Bóg chce, żeby w bitwie nasze woły

Oczy wam kłoły.

Coście niesłusznie pobrali, oddajcie,

Łez ludzkich na się już nie zaciągajcie,

Bo łzy, co ludzie lejąc na was, wyją,

Wszędzie Was biją! ${ }^{47}$

Kością niezgody były oczywiście stacje żołnierskie, które winny być wybierane zgodnie $z$ ustawą hetmańską. Niestety, powszechnie nie stosowano się do ordynansów hetmanów, wybierając naturalia nie według naznaczonej ilości, ale według własnych potrzeb. Jak wyglądał wybór stacji zgodnie $z$ ordynacją hetmańską dla jazdy zaciągu narodowego, widzimy np. w ustawie hibernowej z września 1649 roku. Na poszczególnego towarzysza, tak husarskiego, jak kozackiego, na ćwierć roku miarą sandomierską przypadało:

żyta korcy 3; pszenice korzec 1; jęczmienia korcy 3; grochu korzec 1; krup korzec 1 ; jagieł ćwierci 1; owsa korcy 12; siana wozów 4; słomy wozów 4; jałowica 1; połeć mięsa 1; masła kwart 15; syrów 30; gęsi 15; oleju kwart 2; baranów 2; kurów 30; drew wozów $13^{48}$.

\footnotetext{
${ }^{47}$ Wojsko odzyskało wiarę we własne siły dopiero w 1660 roku, gdy wraz z posiłkami z Korony (dywizja Stefana Czarnieckiego) udało mu się wyzwolić centralne województwa Wiclkicgo Księstwa Litewskiego z Wilnem i rozbić siły Iwana Chowańskiego pod Połonka; zob. J. Wimmer, Wojsko polskie w drugiej połowie XVII wieku, Warszawa 1965, s. 127.

${ }^{48}$ Wg Dyspozycyi wojska JKMci pro hybernis 1649 Septembris, rps BCzart. 2247, nr 5, s. 59-61.
} 
Była to dystrybuta stacji żołnierskiej na kwartał dla towarzysza, a przecież choragiew stukonna musiała zarekwirować takiego prowiantu znacznie więcej. Kilkusetosobowy pułk jazdy objadał w ten sposób całą okolicę, nie kontentując się włościami królewskimi, ale wchodząc także w prywatne. Rzadko kiedy bowiem wojsko zadowalało się naznaczoną ustawą hibernową „na koń, samo wybierając $z$ łanu ile się dało, co prowadziło do zatargów ze starostami dóbr królewskich, a sprawy te kończyły się z reguły w Trybunale i przed sądami hetmańskimi. Aby zdyscyplinować chorągwie stacjonujące na leżach, często sięgano po środek skuteczny, ale wpływający negatywnie na postawę wojska wobec własnego społeczeństwa: wszelkie szkody, grabieże i przebrania w wybieraniu stacji potrącano poszczególnym choragwiom $\mathrm{z}$ ich żołdu, kładąc areszt na ich zasługi w skarbie publicznym.

Z obawy przed kilkakrotnym przebraniem ustawy hibernowej naznaczano „na koń" z łanu konkretną sumę, ale nie miało to większego znaczenia dla towarzystwa chorągiewnego. Dla przykładu: hetman wielki koronny Stanisław Rewera Potocki, wydając ordynans do dwóch choragwi tatarskich (Stanisława Łazińskiego oraz Stefana Bidzińskiego, starosty chęcińskiego, pod dowództwem Bruckiego) żądał, aby ustąpili z Łucka i Włodzimierza, gdzie miały odbywać się zjazdy przedsejmowe, i

...wydanym chlebem $\mathrm{z}$ tych miast według ustawy generalnej po złotych $40 \mathrm{z}$ łanu kontentowali się, także i z władyctwa łuckiego wziąwszy po złotych $20 \mathrm{z}$ łanu, i abyście do innych miejsc ustąpili ${ }^{49}$.

Oczywiście z zachowanych akt procesowych wynika, że i w tym wypadku towarzystwo choragiewne przebrało znacznie ustawę, wybierając $z$ łanu o wiele większe sumy niż to wynikało $z$ ordynansu hetmana.

Z przedstawionego sporu pomiędzy towarzystwem choragwi husarskiej JKMci a Nowogrodzianami wynika, że ci ostatni mimo swej nikłej liczebności skutecznie replikowali na oskarżenia wojska. A przecież, zgodnie z popisem obywateli tegoż województwa z 1651 roku, nie była to grupa liczna. W spisie figuruje bowiem 250 odrębnych posiadłości i około 400 osób, w tym 12 kobiet. Dominowała jednak drobna i biedna szlachta, skoro aż w 67 wypadkach wystawienie jednego jeźdźca obciążało dwu i więcej posiadaczy, a po jednym jeźdźcu wystawiało 119 posiada$\mathrm{czy}^{50}$. Nie dziwi zatem, że ostro przeciwstawiali się wszelkim gwałtom dokonywanym przez choragwie komputowe, które niszczyły ich dobra.

Zresztą wyczyny chorągwi litewskich w tym względzie nie odbiegały od normy. Obawa przed wojskiem, i to własnym, była silniejsza niż uznanie i podziw. Właśnie na taką postawę szlachty istotny wpływ miały zniszczenia dokonywane przez nieopłacone chorągwie, w tym wypadku husarię litewską. Szczególnie rota husarii Jana Kazimierza pod komendą pisarza polnego litewskiego Aleksandra Połubińskiego ${ }^{51}$ zaznaczyła się wieloma rozbojami i często występuje w aktach

\footnotetext{
49 S. Potocki do choragwi tatarskich z Podhajec 14 I 1666 - Centralne Państwowe Archiwum Historyczne Ukrainy w Kijowie, zespół 25, inwentarz I, nr 313, k. 76-77.

50 Zob. H. Wisner, Przedsejmowy sejmik nowogrodzki w latach 1607-1648, op. cit., s. 677.

51 Zob. jego biogram w Polskim slowniku biograficznym, t. 27, Wrocław 1983, s. 358-363 (autor hasła: M. Nagiclski).
} 
procesowych skarżona o gwałty i szkody wyrządzane w dobrach szlacheckich. Rejestr ten jest obfity, począwszy od jej powstania aż po zwinięcie jednostki w 1666 roku. Ograniczymy się jedynie do kilku przykładów, aby Czytelnikowi uzmysłowić, że nie byli to „barankowie”, jak to wynika z poezji okolicznościowej stworzonej przez jej towarzystwo.

W latach 1663-1664 czeladź i towarzystwo tej roty poczyniło wiele rozbojów na konsystencjach w Mińsku i okolicach. Powtórzyła się zatem sytuacja z roku 1659, gdy do takich ekscesów doszło w Nowogródczyźnie i w Kurlandii. Relację z wyczynów towarzystwa tej choragwi składał Bogusławowi Radziwiłłowi jego sługa, Jan Cedrowski, podczaszy nowogródzki. Pisał wówczas:

Teraz wielką penuryją [niedostatek - M. N.] cierpi włość W. Ks. Mci smolewicka od czeladzi chorągwi królewskiej usarskiej, która ma swoją konsystencyją w Mińsku. Muszę się panu komendantowi wysługiwać ${ }^{52}$.

We wrześniu 1663 roku rozboje w wykonaniu towarzystwa tej roty powtórzyly się. Cedrowski ponownie donosił swemu pryncypałowi:

Gorsza była chorąiew usarska Króla, która stała w Mińsku; ta bez wszelkiego respektu i po dworach szlacheckich gospody pisali i straszne czynili egzakcyje [wybieranie dóbr — M. N.], także połowę ludzi z Mińska rozegnali. Mają wielką poddani W. Ks. Mci od ichmość panów [towarzystwa - M. N.] krzywdę ${ }^{53}$.

W Mińszczyźnie w sierpniu 1664 roku ponownie dało o sobie znać towarzystwo spod znaku pisarza polnego litewskiego. Świadkiem incydentu $z$ tą rotą był znany pamiętnikarz Jan Antoni Chrapowicki, który w diariuszu pod datą 1 sierpnia zanotował:

Wyjechawszy z Łumszyna rano, pokarmiłem z Oszmiańcach do Mińska na nieszpor przyjechawszy, gdzie chorągiew husarska JKMci nie rano przyszła, a wczora był tu hałas pacholików ichże z miastem.

Kilka dni później, 5 sierpnia, towarzystwo królewskie znowu znalazło się na kartach jego pamiętnika:

Tamże w klasztorze [panien Benedyktynek - M. N.] hałas z jakimsi Szostowickim Piotrem spod choragwie KJMci, który naszedł na klasztor i dla obserwancyjej, cało wyszedł, chwała Bogu! ${ }^{54}$

Obraz wojska litewskiego byłby jednak niepełny i przedstawiony w krzywym zwierciadle, gdybyśmy nie uwzględnili wielu istotnych problemów wpływających na jego stan i funkcjonowanie, takich choćby jak:

— stałe zaległości płatnicze skarbu litewskiego wobec wojska;

${ }_{52}$ J. Cedrowski do Bogusława Radziwiłła z Otrubka 10 IV 1663 - AGAD, AR, dz. V, teka 43, nr 1867.

${ }^{53}$ Tenże do tegoż z Otrubka 6 IX 1663 - ibidem.

54 J. A. Chrapowicki, Diariusz, cz. 1: lata 1656-1664, wyd. T. Wasilewski, Warszawa 1978, s. 506-508. 
— niski żołd (51 złotych polskich dla husarza za przesłużoną ćwierć), niepokrywający potrzeb towarzystwa, nie wspominając o zakupie broni, koni i rynsztunku;

- zróżnicowany skład społeczno-narodowy armii litewskiej, co nie ułatwiało dowodzenia i utrzymania żołnierza w należytej dyscyplinie, zarówno w trakcie działań, jak i na leżach.

Także konflikty ze społeczeństwem szlacheckiej Rzeczypospolitej nie zawsze kończyły się sukcesem żołnierzy. Niejednokrotnie to oni byli stroną przegraną w orężnych sporach z gminami chłopskimi. Akta procesowe są tego najlepszym przykładem. Stąd na podstawie niniejszej konfrontacji towarzystwa husarii JKMci z Nowogrodzianami trudno jednoznacznie stwierdzić, że wojsko litewskie było dla społeczności Wielkiego Księstwa Litewskiego jedynie ciężarem — masowe skargi na przechodzące oddziały rzeczywiście obraz ten rysują w czarnych kolorach. Prawda jednak była bardziej złożona niż to wynika z przeglądanych diariuszy i pamiętników epoki. 